\title{
UJI EFEKTIVITAS PUPUK ORGANONITROFOS DENGAN PUPUK KIMIA PADA TANAMAN CABAI RAWIT KATHUR (Capsicum frutescens) DI TANAH ULTISOL
}

\author{
Bella Christine, Jamalam Lumbanraja, Dermiyati \& Sutopo Ghani Nugroho \\ Jurusan Agroteknologi, Fakultas Pertanian Universitas Lampung \\ Jl.Prof. Soemantri Brodjonegoro, No.1, Bandar Lampung 35145 \\ E-mail: bellachristine90@gmail.com
}

\begin{abstract}
ABSTRAK
Pupuk Organonitrofos merupakan salah satu jenis pupuk organik yang berasal dari hasil dekomposisi campuran kotoran sapi segar dan batuan fosfat alam yang baru dikembangkan di Provinsi Lampung. Penelitan ini bertujuan untuk mempelajari uji efektivitas dan pengaruh pupuk Organonitrofos dan kombinasinya dengan pupuk kimia terhadap pertumbuhan, serapan hara dan produksi tanaman cabai rawit kathur. Penelitian dilaksanakan pada bulan Mei hingga Oktober 2012 di Laboratorium Lapang Terpadu dan Laboratorium Ilmu Tanah Universitas Lampung. Penelitian ini terdiri dari 6 perlakuan dengan 3 ulangan

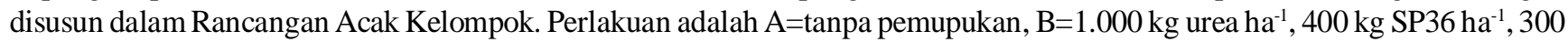

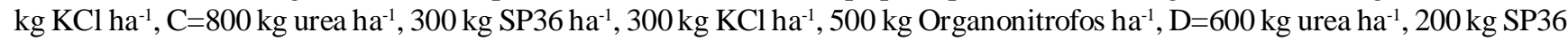

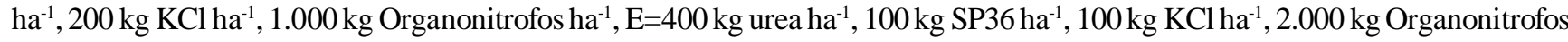
$\mathrm{ha}^{-1}, \mathrm{~F}=5.000 \mathrm{~kg}$ Organonitrofos $\mathrm{ha}^{-1}$. Homogenitas ragam diuji dengan uji Bartlet, aditivitas data diuji dengan uji Tukey. Perbedaan nilai tengah perlakuan diuji dengan uji Beda Nyata Terkecil pada taraf 5\%. Hasil penelitian menunjukkan bahwa:(1) Perlakuan pupuk kombinasi E (400 kg urea ha-1, $100{\mathrm{~kg} \mathrm{SP} 36 \mathrm{ha}^{-1}, 100 \mathrm{~kg} \mathrm{KCl} \mathrm{ha}}^{-1}$, $2.000 \mathrm{~kg}$ Organonitrofos ha-1) dan pupuk Organonitrofos tunggal dengan dosis $5.000 \mathrm{~kg} \mathrm{ha}^{-1}$ efektif terhadap produksi secara RAE masing-masing sebesar 47 dan $176 \%$, serta perlakuan pupuk Organonitrofos tunggal menunjukkan yang paling ekonomis (2) Kombinasi pupuk Organonitrofos

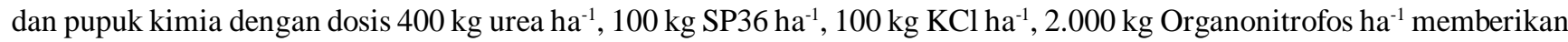
pengaruh terbaik terhadap pertumbuhan dan serapan hara NPK, sedangkan produksi terbaik terdapat pada perlakuan pupuk Organonitrofos tunggal dengan dosis $5.000 \mathrm{~kg} \mathrm{ha}^{-1}$.
\end{abstract}

Kata kunci : Anorganik, cabai rawit kathur, organonitrofos, pupuk organik

\section{PENDAHULUAN}

Permintaan produk cabai cenderung terus meningkat sehingga dapat diandalkan sebagai komoditas nonmigas. Berdasarkan data BPS (2012), Provinsi Lampung memiliki potensi produksi cabai yang cukup besar. Hal ini terlihat dari meningkatnya produksi total cabai dari tahun 2009 sampai 2011 yang mencapai 100\% yaitu dari 28.000 ton menjadi 56.000 ton dengan luasan lahan yang hampir sama sekitar 7.500 ha. Peningkatan yang signifikan ini diduga karena petani melakukan intensifikasi pertanian, salah satunya dengan penggunaan pupuk kimia. Lestari (2009) menyatakan bahwa peningkatan produktivitas ini dapat disebabkan oleh penggunaan pupuk kimia yang sangat tinggi. Tetapi input berupa pupuk yang tinggi ini bisa menjadi masalah berupa degradasi tanah.

Degradasi tanah yang disebabkan oleh penggunaan pupuk kimia dapat diatasi dengan menambahkan pupuk organik. Adapun keuntungan dari pupuk organik adalah memperbaiki sifat fisik tanah, antara lain memperbaiki permeabilitas tanah, porositas tanah dan daya pegang tanah terhadap air sehingga tersedia bagi tanaman, struktur tanah menjadi lebih baik sehingga tanah menjadi gembur dan pertumbuhan akar tanaman lebih baik (Chairani, 2006). Untuk tetap mempertahankan produksi tanaman yang tinggi maka perlu dilakukan kombinasi antara pupuk organik dan pupuk kimia.

Pupuk Organonitrofos adalah pupuk organik baru yang dirancang oleh tim dosen Fakultas Pertanian Universitas Lampung. Pupuk Organonitrofos ini merupakan salah satu jenis pupuk organik yang berasal dari hasil dekomposisi campuran kotoran sapi segar dan batuan fosfat alam (Nugroho dkk., 2012). Kelebihan pupuk Organonitrofos adalah kandungan $\mathrm{N}$ dan $\mathrm{P}$ yang lebih tinggi dari pupuk organik lainnya. Hal ini disebabkan karena ditambahkannya mikroba pelarut fosfat dan penambat N. Kedua mikroba ini dapat menyediakan unsur hara $\mathrm{N}$ dan $\mathrm{P}$ bagi tanaman. Sebagai salah satu 
jenis pupuk organik baru, maka perlu dilakukan uji untuk mengetahui efektivitasnya dalam pertumbuhan dan hasil produksi tanaman cabai rawit kathur (Nugroho dkk., 2013).

Penelitian ini bertujuan untuk : (1) Menguji efektivitas pupuk Organonitrofos maupun kombinasinya dengan pupuk kimia secara agronomis (RAE) dan ekonomis pada tanaman cabai rawit kathur (2) Mengetahui pengaruh pupuk Organonitrofos dan kombinasinya dengan pupuk kimia terhadap pertumbuhan, serapan hara dan produksi tanaman cabai rawit kathur.

\section{BAHAN DAN METODE}

Penelitian ini dilakukan di Laboratorium Lapang Terpadu dan Laboratorium Ilmu Tanah, Fakultas Pertanian Universitas Lampung dari bulan Mei 2012 sampai Oktober 2012. Sebelum dimulai percobaan contoh tanah awal diambil untuk dianalisis sifat kimianya, demikian pula contoh pupuk untuk sifat kimia pupuk Organonitrofos. Persiapan percobaan dimulai dengan pembersihan lahan, pencangkulan, dan pembuatan petak percobaan. Petak percobaan berukuran $3 \times 3$ m dengan jarak tanam $0,5 \mathrm{mx} 0,5 \mathrm{~m}$.

Perlakuan percobaan terdiri dari 6 (enam) paket dosis pupuk yaitu $\mathrm{A}=$ tanpa pemupukan, $\mathrm{B}=1.000 \mathrm{~kg}$ urea ha- ${ }^{-1}, 400 \mathrm{~kg} \mathrm{SP} 6 \mathrm{ha}^{-1}, 300 \mathrm{~kg} \mathrm{KCl} \mathrm{ha}{ }^{-1}, \mathrm{C}=800$ $\mathrm{kg}$ urea ha ${ }^{-1}, 300 \mathrm{~kg} \mathrm{SP} 36 \mathrm{ha}^{-1}, 300 \mathrm{~kg} \mathrm{KCl} \mathrm{ha}^{-1}, 500 \mathrm{~kg}$ Organonitrofos ha-1 $\mathrm{h}^{-1} \mathrm{D}=600 \mathrm{~kg}$ urea ha- ${ }^{-1}, 200 \mathrm{~kg}$ SP36 ha-1 $, 200 \mathrm{~kg} \mathrm{KCl} \mathrm{ha}^{-1}, 1.000 \mathrm{~kg}$ Organonitrofos $\mathrm{ha}^{-1}, \mathrm{E}=400 \mathrm{~kg}$ urea ha ${ }^{-1}, 100 \mathrm{~kg} \mathrm{SP} 36 \mathrm{ha}^{-1}, 100 \mathrm{~kg}$ $\mathrm{KCl} \mathrm{ha}{ }^{-1}, 2.000 \mathrm{~kg}$ Organonitrofos $\mathrm{ha}^{-1}, \mathrm{~F}=5.000 \mathrm{~kg}$ Organonitrofos ha- ${ }^{-1}$. Perlakuan diulang sebanyak 3 (tiga) kali. Percobaan dilakukan menggunakan sistem rancangan acak kelompok (RAK) dengan pengelompokan berdasarkan topografi.

Bibit cabai yang baik kemudian ditanam dengan jarak tanam $50 \mathrm{~cm}$ x $100 \mathrm{~cm}$. Pembuatan lubang tanam dilakukan dengan menggunakan tugal dengan kedalaman $10 \mathrm{~cm}$. Pemberian pupuk Organonitrofos dan pupuk anorganik (SP36 dan $\mathrm{KCl}$ ) diberikan saat tanam. Pupuk urea diberikan dalam dua tahap, yaitu pada saat tanam dan saat berbunga. Penyiraman tanaman dilakukan setiap hari karena percobaan ini dilakukan pada musim kemarau. Untuk menjaga kelembaban air tanah dan mencegah serangan penyakit dari percikan air tanah digunakan mulsa jerami.

Pengamatan dilakukan terhadap tinggi tanaman, jumlah cabang, bobot segar buah, bobot berangkasan, dan serapan NPK. Terhadap data yang didapat tersebut kemudian dilakukan uji kehomogenitasan data dengan uji Bartlett, sifat aditivitas data dengan uji Tukey, analisis ragam, dan uji lanjut dengan BNT taraf 5\%. Untuk menilai efektivitas pupuk organik dan kombinasinya dengan pupuk kimia dilakukan analisis Relative Agronomic Effectiveness (RAE) yang merupakan perbandingan antara kenaikan hasil karena penggunaan pupuk yang sedang diuji dengan kenaikan hasil pada pupuk standar dikalikan 100\% (Mackay dkk., 1984). Selain itu dilakukan juga uji ekonomis pupuk dengan membuat perhitungan ratio penerimaan dengan pengeluaran pupuk, dengan rumus (Ismono, 2013) :

Keterangan:

$$
\text { Ratio }=\frac{\mathrm{P} \times \mathrm{Q}}{\mathrm{C}}
$$

$\mathrm{P}=$ harga cabai $(\mathrm{Rp} / \mathrm{kg})$

$\mathrm{Q}=$ jumlah produksi panen cabai $(\mathrm{kg} / \mathrm{ha})$

$\mathrm{C}=$ biaya pupuk $(\mathrm{Rp} / \mathrm{ha})$.

\section{HASIL DAN PEMBAHASAN}

Berdasarkan hasil analisis awal (Tabel 1), Tanah Ultisol yang digunakan dalam penelitian ini lebih subur dibandingkan dengan tanah Ultisol pada umumnya. Hal ini diduga karena lahan yang digunakan baru dibuka dari semak belukar. Dengan adanya vegetasi diatas tanah maka akan terjadi proses pelapukan yang kemudian

Tabel 1 . Hasil Analisis Tanah Awal dan Pupuk Organonitrofos.

\begin{tabular}{lccc}
\hline \multicolumn{1}{c}{ Analisis } & Tanah & Kriteria & Pupuk Organonitrofos \\
\hline $\mathrm{pH}\left(\mathrm{H}_{2} \mathrm{O}\right)$ & 6,64 & Netral & 7,6 \\
C-organik Walkey \& Black $(\%)$ & 2,31 & Sedang & 21,51 \\
N-total Kjedahl $(\%)$ & 0,24 & Sedang & 1,32 \\
P-total $\mathrm{HCl} \mathrm{25 \% ( \% )}$ & 0,03 & Sedang & 0,33 \\
K-total HCl 25\% $(\%)$ & 0,025 & Sedang & 0,48 \\
P-tersedia Bray 1 (ppm) & 8,87 & Sedang & \\
K-dd (cmol 100 $\left.\mathrm{kg}^{-1}\right)$ & 0,48 & Sedang & \\
\hline
\end{tabular}

Sumber kriteria : Balittanah (2005) 
membentuk humus. Hal ini sesuai dengan pendapat Aprianis (2009) bahwa setelah mengalami penguraian atau proses dekomposisi, serasah menjadi senyawa organik sederhana dan menghasilkan hara, sehingga dapat langsung dimanfaatkan oleh tanaman.

Hasil analisis pupuk Organonitrofos menunjukkan bahwa derajat kemasaman $(\mathrm{pH})$ pupuk sebesar 7,6. Nilai C-organik 21,51\%, P-total 0,33\%, K-total 0,48\% dan $\mathrm{N}$-total $1,32 \%$. Nilai tersebut lebih tinggi jika dibandingkan dengan pupuk organik biasa karena pupuk Organonitrofos berasal dari hasil dekomposisi campuran kotoran sapi segar dan batuan fosfat alam serta ditambahkan N-Fikser (Azotobacter sp, Azospirilum $\mathrm{sp}$ ) dan P-Solubilizer (Aspergillus niger dan Pseudomonas fluorescens) yang diharapkan akan meningkatkan produktivitas tanah Ultisol.

Pada masa pertumbuhan tanaman cabai rawit kathur, variabel yang diamati ialah tinggi dan jumlah cabang. Pada 6 MST perlakuan $\mathrm{E}=400 \mathrm{~kg}^{\mathrm{urea}} \mathrm{ha}^{-1}$,
$100 \mathrm{~kg} \mathrm{SP} 36 \mathrm{ha}^{-1}, 100 \mathrm{~kg} \mathrm{KCl} \mathrm{ha}{ }^{-1}, 2.000 \mathrm{~kg}$ Organonitrofos ha ${ }^{-1}$ dan $\mathrm{F}=5.000 \mathrm{~kg}$ Organonitrofos ha $^{-1}$ nyata meningkatkan tinggi tanaman dibandingkan perlakuan lainnya. Sedangkan pada 9 dan 12 MST semua perlakuan pemupukan baik pupuk anorganik tunggal, organik tunggal maupun kombinasinya tidak berbeda nyata terhadap tinggi tanaman, namun berbeda nyata dengan perlakuan tanpa pupuk (Tabel 2). Menurut Badan Litbang Pertanian (2011) masa vegetatif maksimum tanaman cabai ialah 30-40 hari setelah tanam atau 4-5 MST. Setiap perlakuan pemupukan pada 5-9 MST terjadi peningkatan tinggi tanaman berkisar 7-20 $\mathrm{cm}$, sedangkan pada rentang waktu 9-12 MST tinggi tanaman bertambah antara $1-5 \mathrm{~cm}$.

Hasil uji BNT (Tabel 3) menunjukkan bahwa pada 3 MST, aplikasi pupuk Organonitrofos tunggal dengan dosis $5.000 \mathrm{~kg} \mathrm{ha}^{-1}$, pupuk kimia tunggal maupun kombinasi pupuk Organonitrofos dan pupuk kimia memiliki jumlah cabang yang tidak berbeda namun

Tabel 2. Pengaruh pemupukan Organonitrofos dan kombinasinya dengan pupuk kimia terhadap tinggi tanaman cabai rawit kathur (cm).

\begin{tabular}{lccc}
\hline $\begin{array}{c}\text { Perlakuan } \\
\text { Urea - SP36 - KCl - Organonitrofos }\end{array}$ & 6 MST & 9 MST & 12 MST \\
\hline A $(0-0-0-0)$ & $23,36 \mathrm{c}$ & $37,95 \mathrm{~b}$ & $47,31 \mathrm{~b}$ \\
B $(1.000-400-300-0)$ & $33,24 \mathrm{~b}$ & $56,94 \mathrm{a}$ & $65,16 \mathrm{a}$ \\
C $(800-300-500-500)$ & $34,10 \mathrm{~b}$ & $57,69 \mathrm{a}$ & $66,06 \mathrm{a}$ \\
D $(600-200-200-1.000)$ & $34,20 \mathrm{~b}$ & $56,72 \mathrm{a}$ & $64,46 \mathrm{a}$ \\
E $(400-100-100-2.000)$ & $38,76 \mathrm{a}$ & $63,59 \mathrm{a}$ & $70,49 \mathrm{a}$ \\
F $(0-0-0-5.000)$ & $36,82 \mathrm{ab}$ & $66,37 \mathrm{a}$ & $72,62 \mathrm{a}$ \\
\hline BNT 0,05 & 3,94 & 11,88 & 11,65 \\
\hline
\end{tabular}

Keterangan: Angka yang diikuti huruf yang sama pada kolom yang sama tidak berbeda nyata pada uji BNT dengan taraf $5 \%$.

Tabel 3. Pengaruh pemupukan Organonitrofos dan kombinasinya dengan pupuk kimia terhadap jumlah cabang tanaman cabai rawit kathur (buah tanaman ${ }^{-1}$ ).

\begin{tabular}{lccc}
\hline \multicolumn{1}{c}{ Perlakuan } & 3 MST & $6 \mathrm{MST}$ & 9 MST \\
Urea - SP36 - KCl - Organonitrofos & & $1,42 \mathrm{c}$ & $1,5 \mathrm{~d}$ \\
A $(0-0-0-0)$ & $1,00 \mathrm{~b}$ & $2,60 \mathrm{ab}$ & $3,53 \mathrm{bc}$ \\
B $(1.000-400-300-0)$ & $2,57 \mathrm{a}$ & $2,43 \mathrm{ab}$ & $3,2 \mathrm{bc}$ \\
C $(800-300-500-500)$ & $1,75 \mathrm{ab}$ & $2,26 \mathrm{bc}$ & $2,86 \mathrm{c}$ \\
D $(600-200-200-1.000)$ & $1,72 \mathrm{ab}$ & $3,21 \mathrm{a}$ & $4,6 \mathrm{a}$ \\
E $(400-100-100-2.000)$ & $2,48 \mathrm{a}$ & $2,72 \mathrm{ab}$ & $3,60 \mathrm{~b}$ \\
F $(0-0-0-5.000)$ & $2,51 \mathrm{a}$ & 0,87 & 0,7 \\
\hline BNT 0,05 & 0,92 & & \\
\hline
\end{tabular}

Keterangan: Angka yang diikuti huruf yang sama pada kolom yang sama tidak berbeda nyata pada uji BNT dengan taraf $5 \%$. 
memiliki lebih banyak jumlah cabang dibandingkan perlakuan tanpa pupuk (kontrol). Pada 9 MST, perlakuan $\mathrm{E}=400 \mathrm{~kg}$ urea ha- ${ }^{-1}, 100 \mathrm{~kg} \mathrm{SP} 36 \mathrm{ha}^{-1}, 100 \mathrm{~kg} \mathrm{KCl} \mathrm{ha}$ ${ }^{1}, 2.000 \mathrm{~kg}$.

Organonitrofos ha-1 memiliki jumlah cabang terbanyak dan berbeda dibandingkan perlakuan lainnya. Pada 12 MST semua perlakuan bersifat tidak nyata terhadap jumlah cabang. Hal ini disebabkan pada masa vegetatif akhir tanaman, unsur hara yang diserap dialokasikan untuk masa generatif atau produksi tanaman. Hal ini sejalan dengan pendapat Yasuo (2000) yang menyatakan bahwa sebanyak $76 \%$ unsur $\mathrm{N}$ pada tanaman diserap setelah fase generatif dan $70 \%$ nya dialokasikan langsung menuju bagian buah atau bagian tempat penyimpanan $(\operatorname{sink})$.

Perlakuan pemupukan kimia tunggal (Perlakuan B) dengan dosis $1.000 \mathrm{~kg}$ urea ha-1, $400 \mathrm{~kg} \mathrm{SP} 36 \mathrm{ha}^{-1}$, $300 \mathrm{~kg} \mathrm{KCl} \mathrm{ha-1}$ memberi serapan hara $\mathrm{N}$ tertinggi dibandingkan perlakuan yang lainnya. Hal ini diduga karena pupuk urea yang diberikan merupakan dosis tinggi yaitu $1.000 \mathrm{~kg}$. Pupuk urea memiliki sifat fast release atau cepat tersedia. Pada serapan hara $\mathrm{P}$ dan $\mathrm{K}$ tertinggi terdapat pada perlakuan pemupukan kombinasi dengan dosis $400 \mathrm{~kg} \mathrm{urea} \mathrm{ha}^{-1}, 100 \mathrm{~kg} \mathrm{SP} 36$ ha $^{-1}, 100 \mathrm{~kg} \mathrm{KCl} \mathrm{ha}^{-1}$, dan $2.000 \mathrm{~kg}$ Organonitrofos ha${ }^{1}$ (Perlakuan E). Pupuk kombinasi tersebut mampu memberikan nutrisi dengan jumlah cukup yang dibutuhkan bagi tanaman. Hal ini sesuai dengan kandungan $\mathrm{P}$ dan $\mathrm{K}$ dalam pupuk Organonitrofos yang tergolong sangat tinggi (Tabel 4). Menurut Narayan dkk. (2004), serapan hara maksimum tanaman cabai adalah sebesar 134,56 kg ha ${ }^{-1} \mathrm{~N}, 14,91 \mathrm{~kg} \mathrm{ha}^{-1} \mathrm{P}$, dan 104, 46 $\mathrm{kg} \mathrm{ha}^{-1} \mathrm{~K}$ atau berkisar antara 6,73 $\mathrm{g} \mathrm{N}, 0,75 \mathrm{~g} \mathrm{P}$ dan $5,23 \mathrm{~g} \mathrm{~K}$ per tanaman yang dihasilkan oleh kombinasi $50 \%$ pupuk NPK dan $50 \%$ bahan organik. Hal ini menunjukkan bahwa perlakuan kombinasi pupuk kimia dan Organonitrofos mampu menunjang serapan hara $\mathrm{N}$ untuk tanaman.

Pada variabel pengamatan bobot segar buah hasil uji BNT menunjukkan bahwa perlakuan pupuk Organonitrofos tunggal dengan dosis $5.000 \mathrm{~kg} \mathrm{ha}^{-1}$ meningkatkan bobot segar buah dan bobot kering cabai rawit kathur dibandingkan perlakuan lainnya (Tabel 5). Hal ini ditunjukkan oleh produksi tanaman cabai rawit kathur yang diberi pupuk Organonitrofos dengan dosis $5.000 \mathrm{~kg} \mathrm{ha}^{-1}$ berbeda nyata dibandingkan dengan kontrol dan juga pupuk kimia dengan dosis $1.000 \mathrm{~kg}$ urea ha $^{-1}$, $400 \mathrm{~kg} \mathrm{SP} 6 \mathrm{ha}^{-1}, 300 \mathrm{~kg} \mathrm{KCl} \mathrm{ha}^{-1}$. Sama halnya dengan bobot segar buah, dosis pupuk Organonitrofos sebesar $5.000 \mathrm{~kg} \mathrm{ha}^{-1}$ menghasilkan bobot kering buah tertinggi yang berbeda terhadap perlakuan lain kecuali perlakuan dengan dosis $400 \mathrm{~kg} \mathrm{ha}^{-1}$ urea, $100 \mathrm{~kg} \mathrm{ha}^{-1} \mathrm{SP} 36,100 \mathrm{~kg}$ $\mathrm{ha}^{-1} \mathrm{KCl}$ dan $2.000 \mathrm{~kg} \mathrm{ha}^{-1}$ Organonitrofos.

Bobot brangkasan menunjukkan tingkat efesiensi metabolisme dari suatu tanaman. Jika bobot brangkasan tinggi maka reaksi metabolisme berjalan baik, karena tanaman memiliki daun yang kokoh sehingga proses fotosintesis berjalan lancar (Taufik, 2000). Berdasarkan hasil uji BNT (Tabel 6) bahwa perlakuan E (400 kg urea ha $^{-1}, 100 \mathrm{~kg} \mathrm{SP} 36 \mathrm{ha}^{-1}, 100 \mathrm{~kg} \mathrm{KCl} \mathrm{ha}{ }^{-1}, 2.000 \mathrm{~kg}$ Organonitrofos ha ${ }^{-1}$ ) memiliki bobot brangkasan tertinggi yang tidak berbeda nyata dengan perlakuan $\mathrm{F}=5.000$

Tabel 4. Pengaruh pemupukan Organonitrofos dan kombinasinya dengan pupuk kimia terhadap serapan hara total tanaman cabai rawit kathur $\left(\mathrm{kg} \mathrm{ha}^{-1}\right)$.

\begin{tabular}{|c|c|c|c|}
\hline \multirow{2}{*}{ Perlakuan } & \multicolumn{3}{|c|}{ Serapan hara } \\
\hline & $\mathrm{N}$-total & P-total & K-total \\
\hline A & $50,98 \quad \mathrm{~d}$ & $2,89 \mathrm{~d}$ & 16,02 \\
\hline B & 104,73 a & $5,22 \quad b$ & 19,46 \\
\hline $\mathrm{C}$ & 89,35 & $5,39 \quad \mathrm{~b}$ & 19,64 \\
\hline $\mathrm{D}$ & $61,50 \mathrm{~cd}$ & $4,23 \mathrm{c}$ & 18,61 \\
\hline $\mathrm{E}$ & $97,91 \quad a b$ & 7,26 a & 25,11 \\
\hline $\mathrm{F}$ & $69,73 \quad \mathrm{c}$ & 6,62 a & 22,24 \\
\hline BNT 0,5 & 13,85 & 0,98 & 2,47 \\
\hline
\end{tabular}

Keterangan: angka yang diikuti huruf yang sama pada kolom yang sama tidak berbeda nyata pada uji BNT dengan taraf 5\%. A = tanpa pemupukan (Kontrol); B $=1.000 \mathrm{~kg} u r e a ~ h a^{-1}, 400 \mathrm{~kg} \mathrm{SP}^{2} \mathrm{ha}^{-1}, 300 \mathrm{~kg} \mathrm{KCl} \mathrm{ha}^{-}$

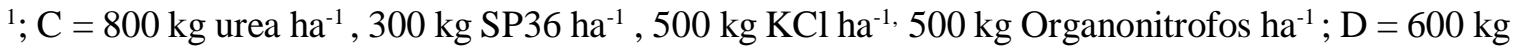

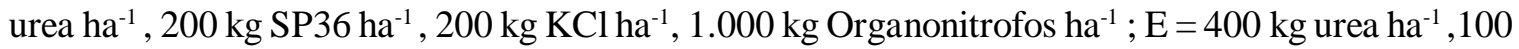
$\mathrm{kg} \mathrm{SP36} \mathrm{ha-1,} 100 \mathrm{~kg} \mathrm{KCl} \mathrm{ha}^{-1}, 2.000 \mathrm{~kg}$ Organonitrofos ha- ${ }^{-1} ; \mathrm{F}=5.000 \mathrm{~kg}$ Organonitrofos ha ${ }^{-1}$ 
Tabel 5. Pengaruh pemupukan Organonitrofos dan kombinasinya dengan pupuk kimia terhadap bobot segar buah dan bobot kering buah cabai rawit kathur.

\begin{tabular}{lcc}
\hline $\begin{array}{c}\text { Perlakuan }\left(\mathrm{kg} \mathrm{ha}^{-1}\right) \\
\text { Urea }-\mathrm{SP36}-\mathrm{KCl}-\text { Organonitrofos }\end{array}$ & $\begin{array}{c}\text { Bobot segar buah } \\
\left(\mathrm{t} \mathrm{ha}^{-1}\right)\end{array}$ & $\begin{array}{c}\text { Bobot kering buah } \\
\left(\mathrm{t} \mathrm{ha}^{-1}\right)\end{array}$ \\
\hline A $(0-0-0-0)$ & $0,40 \mathrm{e}$ & $0,07 \mathrm{~b}$ \\
$\mathrm{~B}(1.000-400-300-0)$ & $1,13 \mathrm{bc}$ & $0,11 \mathrm{~b}$ \\
C $(800-300-500-500)$ & $0,97 \mathrm{~cd}$ & $0,15 \mathrm{~b}$ \\
D $(600-200-200-1.000)$ & $0,71 \mathrm{de}$ & $0,08 \mathrm{~b}$ \\
E $(400-100-100-2.000)$ & $1,48 \mathrm{~b}$ & $0,23 \mathrm{ab}$ \\
F $(0-0-0-5.000)$ & $2,42 \mathrm{a}$ & $0,31 \mathrm{a}$ \\
\hline BNT 5\% & 0,39 & 0,16 \\
\hline
\end{tabular}

Keterangan: Angka yang diikuti huruf yang sama pada kolom yang sama tidak berbeda nyata pada uji BNT dengan taraf $5 \%$

Tabel 6. Pengaruh pemupukan Organonitrofos dan kombinasinya dengan pupuk kimia terhadap bobot brangkasan tanaman cabai rawit kathur.

\begin{tabular}{|c|c|c|}
\hline $\begin{array}{c}\text { Perlakuan }\left(\mathrm{kg} \mathrm{ha}^{-1}\right) \\
\text { Urea - SP36 - KCl - Organonitrofos }\end{array}$ & $\begin{array}{l}\text { Bobot basah } \\
\left(\text { ton ha }{ }^{-1}\right)\end{array}$ & $\begin{array}{l}\text { Bobot kering } \\
\left(\text { ton } \mathrm{ha}^{-1}\right)\end{array}$ \\
\hline $\mathrm{A}(0-0-0-0)$ & $2,13 \mathrm{~d}$ & $0,86 \mathrm{~d}$ \\
\hline B $(1.000-400-300-0)$ & $5,71 \mathrm{ab}$ & $1,61 \mathrm{ab}$ \\
\hline $\mathrm{C}(800-300-500-500)$ & $4,90 \mathrm{bc}$ & $1,49 \mathrm{bc}$ \\
\hline $\mathrm{D}(600-200-200-1.000)$ & $4,19 \mathrm{c}$ & $1,26 \mathrm{c}$ \\
\hline$E(400-100-100-2.000)$ & $6,55 \mathrm{a}$ & $1,85 \mathrm{a}$ \\
\hline $\mathrm{F}(0-0-0-5.000)$ & $5,37 \mathrm{abc}$ & $1,56 \mathrm{abc}$ \\
\hline BNT $5 \%$ & 1,20 & 0,30 \\
\hline
\end{tabular}

Keterangan: angka yang diikuti huruf yang sama pada kolom yang sama tidak berbeda nyata pada uji BNT dengan taraf $5 \%$

Tabel 7. Hasil perhitungan Relative Agronomic Effectiviness (RAE) pada bobot segar buah cabai rawit kathur dan biomass (bobot kering brangkasan).

\begin{tabular}{lcc}
\hline $\begin{array}{c}\text { Perlakuan }\left(\mathrm{kg} \mathrm{ha}^{-1}\right) \\
\text { Urea - SP36 - KCl - Organonitrofos }\end{array}$ & $\begin{array}{c}\text { RAE Bobot segar buah } \\
(\%)\end{array}$ & $\begin{array}{c}\text { RAE Biomass } \\
(\%)\end{array}$ \\
\hline A $(0-0-0-0)$ & 0 & 0 \\
B (100-400-300-0) & 100 & 100 \\
C $(800-300-500-500)$ & 78 & 99 \\
D (600-200-200-1.000) & 42 & 54 \\
E (400-100-100-2.000) & 147 & 132 \\
F (0-0-0-5.000) & 276 & 93 \\
\hline
\end{tabular}

Keterangan : apabila nilai RAE e" 100, maka pupuk yang diuji dinyatakan efektif.

Organonitrofos ha-1 dan B $=1.000 \mathrm{~kg}^{-1}$ urea ha- ${ }^{-1}, 400 \mathrm{~kg}$ SP36 ha-1 $300 \mathrm{~kg} \mathrm{KCl} \mathrm{ha}^{-1}$.

Efektivitas pupuk dihitung dengan menggunakan Relative Agronomic Effectiveness (RAE). RAE adalah perbandingan antara kenaikan hasil karena penggunaan pupuk yang diuji dengan kenaikan hasil pada pupuk standar dikalikan $100 \%$ (Mackay dkk., 1984). Berdasarkan nilai RAE (Tabel 7) dapat diketahui bahwa pemberian pupuk Organonitrofos tunggal dengan dosis $5.000 \mathrm{ha}^{-1}$ (Perlakuan F) dan perlakuan kombinasi E (400 kg urea ha ${ }^{-1}, 100 \mathrm{~kg} \mathrm{SP36} \mathrm{ha-1,} 100 \mathrm{~kg} \mathrm{KCl} \mathrm{ha}^{-1}$, $2.000 \mathrm{~kg}$ Organonitrofos $\mathrm{ha}^{-1}$ ) secara agronomis lebih 
Tabel 8 . Uji Ekonomis pupuk pada tanaman cabai rawit kathur.

\begin{tabular}{lccc}
\hline Perlakuan $\left(\mathrm{kg} \mathrm{ha}^{-1}\right)$ & Pupuk & \multicolumn{2}{c}{ Pupuk non-subsidi $(* *)$} \\
\cline { 3 - 4 } Urea - SP36 - KCl - Organonitrofos & Subsidi $(*)$ & Eceran & Partai Besar \\
\hline A $(0-0-0-0)$ & - & - & - \\
B $(1.000-400-300-0)$ & 11,73 & 3,30 & 6,35 \\
C $(800-300-500-500)$ & 4,54 & 1,74 & 3,12 \\
D $(600-200-200-1.000)$ & 5,82 & 2,48 & 4,07 \\
E $(400-100-100-2.000)$ & 10,27 & 6,15 & 8,43 \\
F $(0-0-0-5.000)$ & 9,54 & 9,54 & 9,54 \\
\hline
\end{tabular}

Keterangan : nilai Ratio >1 maka pupuk yg diuji memiliki nilai ekonomis yang baik, $(*)=$ sumber data didapat dari pedoman pelaksanaan penyediaan pupuk bersubsidi untuk sektor pertanian tahun $2012,(* *)=$ sumber data didapat dari survei pasar.

efektif dibandingkan pupuk standar atau pupuk anorganik dengan dosis urea $1.000 \mathrm{~kg} \mathrm{ha}^{-1}, \mathrm{SP} 36400 \mathrm{~kg} \mathrm{ha}^{-1}, \mathrm{KCl}$ $300 \mathrm{~kg} \mathrm{ha}^{-1}$. Sedangkan nilai RAE untuk biomass total yang bersifat efektif terdapat pada perlakuan kombinasi E (urea $400 \mathrm{~kg} \mathrm{ha}^{-1}$, SP $36200 \mathrm{~kg} \mathrm{ha}^{-1}, \mathrm{KCl} 100 \mathrm{~kg} \mathrm{ha}$ ${ }^{1}$, Organonitrofos $\left.1.000 \mathrm{~kg} \mathrm{ha}^{-1}\right)$. Hal ini menunjukkan bahwa penggunaan pupuk Organonitrofos tunggal maupun pupuk kombinasi dengan pupuk kimia pada dosis $400 \mathrm{~kg}$ urea ha- ${ }^{-1}, 100 \mathrm{~kg} \mathrm{SP} 36 \mathrm{ha}^{-1}, 100 \mathrm{~kg} \mathrm{KCl} \mathrm{ha}^{-1}$, $2.000 \mathrm{~kg}$ Organonitrofos ha ${ }^{-1}$ dapat digunakan sebagai alternatif pengganti pupuk kimia tunggal dalam budidaya tanaman cabai rawit kathur.

Uji ekonomis dihitung dengan cara melihat rasio penerimaan dengan pengeluaran pupuk. Nilai ekonomis tertinggi terdapat pada perlakuan pupuk Organonitrofos tunggal, baik menggunakan pupuk subsidi maupun pupuk non subsidi (Tabel 8). Jadi dapat disimpulkan bahwa pupuk Organonitrofos dengan dosis $5.000 \mathrm{~kg} \mathrm{ha}^{-1}$ lebih direkomendasikan untuk digunakan dalam budidaya tanaman cabai rawit kathur. Perhitungan uji ekonomis didasarkan pada satu periode panen, sehingga pengeluaran pupuk urea yang digunakan untuk uji ekonomis hanya $1 / 2$ dari dosis yang ditetapkan. Seharusnya cabai ini minimal 2 kali panen dengan dosis anjuran pupuk urea $1000 \mathrm{~kg} \mathrm{ha}^{-1}$.

\section{KESIMPULAN}

Dari penelitian ini dapat disimpulkan (1) Perlakuan pupuk kombinasi E (400 kg urea ha-1 $100 \mathrm{~kg} \mathrm{SP36} \mathrm{ha-}$ ${ }^{1}, 100 \mathrm{~kg} \mathrm{KCl} \mathrm{ha} a^{-1}, 2.000 \mathrm{~kg}$ Organonitrofos ha ${ }^{-1}$ ) dan pupuk Organonitrofos tunggal dengan dosis $5.000 \mathrm{~kg}$ $\mathrm{ha}^{-1}$ efektif terhadap produksi secara RAE masingmasing sebesar 47 dan $176 \%$, serta perlakuan pupuk Organonitrofos tunggal menunjukkan yang paling ekonomis.(2) Kombinasi pupuk Organonitrofos dan pupuk kimia dengan dosis $400 \mathrm{~kg}_{\text {urea ha }}{ }^{-1}, 100 \mathrm{~kg} \mathrm{SP} 36$ ha $^{-1}, 100 \mathrm{~kg} \mathrm{KCl} \mathrm{ha}{ }^{-1}, 2.000 \mathrm{~kg}$ Organonitrofos ha ${ }^{-1}$ memberikan pengaruh terbaik terhadap pertumbuhan dan serapan hara NPK, sedangkan produksi terbaik terdapat pada perlakuan pupuk Organonitrofos tunggal dengan dosis $5.000 \mathrm{~kg} \mathrm{ha}^{-1}$.

\section{DAFTAR PUSTAKA}

Aprianis. 2009. Evalusi Kandungan Bio-massa dan Dekomposisi Serasah. Laporan Hasil Penelitian. Balai Penelitian Hutan Penghasil Serat, Kuok. 27 hal.

BPS. 2012. Luas Panen, Produksi dan Produktivitas Cabai, 2009-2011. Sebuah artikel. http://bps.go.id. Diakses pada 17 September 2012.

Badan Litbang Pertanian. 2011. Kiat Sukses Berinovasi Cabai. Agroinovasi Edisi 2-8 Pebruari 2011 No.3391 Tahun XLI hal 2-7.

Balittanah. 2005. Petunjuk Teknis Analisis Tanah, Tanaman, Air dan Pupuk. Departemen Pertanian. Bogor. $136 \mathrm{hlm}$.

Chairani. 2006. Pengaruh fosfor dan pupuk kandang kotoran sapi terhadap sifat kimia tanah dan pertumbuhan tanaman padi (Oryza sativa) pada lahan sawah tadah hujan di Kabupaten Langkat Sumatera Utara. J. Penelitian Pertanian 25(1): 8-17.

Ismono, H. 2013. Uji Ekonomis Pupuk dengan Ratio Pemasukan dan Pengeluaran Pupuk. Komunikasi Pribadi. Jurusan Agribisnis. Fakultas Pertanian. Universitas Lampung. 3 Mei 2013.

Lestari, A.P. 2009. Pengembangan Pertanian Berkelanjutan Melalui Subtitusi Pupuk Anorganik Dengan Pupuk Organik. J. Agronomi (13) 1: 3844. 
Mackay, A.D., J.K. Syers and P.E.H. Gregg. 1984. Ability of chemical extraction

procedures to assess the agronomic effectiveness of phosphate rock materials. New Zealand J. Agric. Res., 27: 219-230.

Narayan, R., G.H. Magray., N. Ahmed., and A. Samanta. 2004. Effect of organic manures on nutrient uptake and quality of capsicum (Capsicum annum var. grossum L.). J. Horticultural 17 (2): 141-144.

Nugroho, S.G., Dermiyati, J. Lumbanraja, S. Triyono, H. Ismono, Y.T. Sari, and E. Ayuandari. 2012. Optimum ratio of fresh manure and grain size of phosphate rock mixture in a formulated compost for organomineral NP fertilizer. $J$. Trop. Soils. 17(2): 21-128.
Nugroho, S.G., Dermiyati, J. Lumbanraja, S. Triyono, H. Ismono, M.K. Ningsih, dan F.Y. Saputri Y.T. 2013. Inoculation effect of $N_{2}$-fixer and $P$ solubilizer into a mixture of fresh manure and phosphate rock formulated as Organonitrofos fertilizer on bacterial and fungal population. J. Trop. Soils. 18 (1): 75-80.

Yasuo, F. 2000. Nitrogen absorption and distribution of muskmelons (Curcumis melon L.) at different growth stages using hydroponics. Journal of Soil Science and Plant Nutrition 71(1):72-81. 